\title{
Substrates on the cuttings rooting of black pepper genotypes
}

\author{
Welington Secundino', Rodrigo Sobreira Alexandre2*, Edilson Romais Schmild ${ }^{3}$, \\ Omar Schmildt ${ }^{3}$, Kristhiano Chagas ${ }^{4}$, Helder Ivo Pandolf Marques ${ }^{3}$ \\ Capixaba Institute for Research, Technical Assistance and Rural Extension, São Mateus, Brazil \\ ${ }^{2}$ Federal University of Espirito Santo, Jerônimo Monteiro, Brazil \\ ${ }^{3}$ Federal University of Espirito Santo, São Mateus, Brazil \\ ${ }^{4}$ Federal University of Viçosa, Viçosa, Brazil \\ *Corresponding author, e-mail: rodrigosobreiraalexandre@gmail.com
}

\begin{abstract}
The soil in the production of clonal seedlings of black pepper (Piper nigrum L.) contributes to fusarium and nematodes infestation in commercial crops, and thus the usage of alternative substrates might be a preventive control measure against these pathogens. The aim of this study was to investigate the rhizogenic behavior of the cultivars Bragantina, laçará and Guajarina of black pepper in different substrates. The experimental design was in randomized blocks in a 3x4 factorial design (cultivars: Bragantina, laçará and Guajarina x substrates: soil + organic compound (18\%), vermiculite, carbonized rice hulls and commercial substrate), with four replications of 16 cuttings each. The evaluated characteristics were: survival (\%); rooting (basal or nodal) (\%); nodal rooting (\%); basal rooting (\%); number of nodal roots; number of basal roots; total number of roots; length of the largest nodal root $(\mathrm{cm})$; basal root length $(\mathrm{cm})$; nodal root volume $\left(\mathrm{cm}^{3}\right)$; basal root volume $\left(\mathrm{cm}^{3}\right)$; Total root volume $\left(\mathrm{cm}^{3}\right)$; nodal root dry mass $(\mathrm{mg})$; basal root dry mass $(\mathrm{mg})$ and the total root dry mass $(\mathrm{mg})$. There are differences within black pepper cultivars as to the characteristics related to the root system. The vermiculite substrate was the most suitable, and carbonized rice hull is not recommended for the adventitious rooting of cuttings of cultivars Bragantina, laçará and Guajarina.
\end{abstract}

Keywords: Piper nigrum L., cutting, cultivars, propagation

Introduction

Different biological activities are attributed to the black pepper (Piper nigrum L.), belonging to the Piperaceae family. In Brazil, this species presents several utilities, being a widely consumed spice; however, the tropical climate of the country favors the development of fungi of the type Aspergillus spp. which produce mycotoxins detected on the grain, such as the aflatoxin $B_{1}$, causing a great problem for being a powerful hepatocarcinogen described in mammals, and is classified in the Group 1 (carcinogenic to humans) by the International Agency of Research on Cancer (Prado et al., 2008). Other utilities are attributed to the black pepper, such as being a larvicide to the Aedes aegypti, of great importance for public health (Simas et al., 2007) and presents yet antibacterial property from its essence oil over food contaminants, in substitution to chemical additives (Trajano et al., 2009).

The two largest national producers of this spice, in decrescent order, are the state of Pará (North) and Espírito Santo (Southeast), highlighting the municipality of São Mateus-ES. Pará and Espírito Santo states presented, in 2015, a production of 32.414 (20.445 ha) and 13.863 (8.071 ha) tons and yield of 2.040 and $3.467 \mathrm{~kg}$ $\mathrm{ha}^{-1}$, respectively (IBGE, 2016). The black pepper producersin the EspíritoSantostatereceived prices 
based in June 2015, by kilogram of the spice, of $R \$ 27,00$ (Conab, 2016). Among the existing black pepper cultivars, the most cultivated in the north of the Espírito Santo state and in Pará are the Bragantina, laçará, Guajarina, Cingapure and Kottanadan. Currently, the commercial cultivar is the Bragantina, whose main characteristic lies on presenting long spikes, with good filling, large fruits and, consequently, culminating in a larger yield.

Even with the prices attractivity, some problems are faced by pepper producers, such as fusariosis (Fusarium solanif. sp. piperis) and the southern root-knot nematode (Meloidogyne incognita), which have, in part, being disseminated through cutting. This technique of vegetative propagation is the more utilized, currently, with the species $P$. nigrum, with good success in function of the maintaining of the characteristics of the selected genetic materials, and some works confirm the efficacy of this method (Serrano et al., 2012; Secundino et al., 2014), where the quality of the root system, such as number, volume and root dry mass is fundamental in the survival and acceptability of the seedling in the field.

The employment of alternative substrates in the production of clonal seedlings of black pepper might be a preventive measure in the control of fusariosis and nematosis. These substrates might also help to increase the quality of the seedling, by proportionating, for example, higher number and, consequently, higher volume of roots. The production of quality seedlings is also related with the choice of adequate substrates, such as the propagule source, propagation method, growth regulators, containers, irrigation systems and nursery ambience.

It was aimed with this work to analyze the rooting of black pepper cultivars cuttings in different substrates.

\section{Material and Methods}

The work was conducted in the Centro Universitário Norte do Espírito Santo (CEUNES) of the Federal University of Espírito Santo (UFES), in the municipality of São Mateus-ES, BR 101 North, $\mathrm{Km} 60,39^{\circ} 51^{\prime 2} 22^{\prime \prime} \mathrm{W}$ and 18०40'16"' S.

The adopted experimental design was in randomized blocks, in a factorial scheme of 3x4 [cultivars: Bragantina, laçará and Guajarina x substrates: soil + organic compound (18\%), vermiculite, semi-carbonized rice hull and commercial substrate], with four repetitions of 16 cuttings each.

The orthotropic herbaceous branches (branches of vertical growth, what is desirable for the vertical growth of the plant and higher production) of the black pepper plant (P. nigrum) of the cvs. Bragantina, laçará and Guajarina of five years of age, of commercial crops, were utilized for the obtaining of the cuttings. The branches were placed in polystyrene boxes containing distilled water. Next, these branches were immediately transported to the nursery, where the individualization of the cuttings in 10 $\mathrm{cm}$ of length with two nodes and one leaf was performed, in which the base of each cutting was excised in simple bevel.

After the preparing of the cuttings, they had their stem immersed until the insertion of the leaf, with exception of the leaf, in talcum with the concentration of $4000 \mathrm{mg} \mathrm{kg}^{-1}$ of indol3-butyric acid (IBA) (Secundino et al., 2014). After the treatment with the auxin, the cuttings were planted with the leaf staying over the surface of the substrates soil (anthill ground) + organic compost - tanned bovine manure (18\%), vermiculite with average particle size, carbonized rice hull and commercial substrate (Pinus bark and coconut fiber), disposed in polyethylene trays with cells of $200 \mathrm{~cm}^{3}$ of volume each. Before the planting, in the referred substrates, orifices (openings) were made, approximately of the size of the cuttings and with higher diameter so that the planting would not remove the talcum with the auxin from the cutting surface. These substrates were irrigated before and after the planting of the cuttings.

The cuttings were kept in nursery covered with doubled layer of transparent polyethylene of 150 micra and irrigation of the intermittent fogging type, with automatic activation, every three minutes and thirty seconds, in which the climatic conditions presented an average of 30.2 ${ }^{\circ} \mathrm{C}$ and $84 \%$ of relative humidity.

The evaluated characteristics after 90 days of experiment placement were: survival 
(\%); rooting (independently if the root appeared in the basal or nodal region); nodal rooting (\%); basal rooting (\%); number of nodal, basal and total rootings; length of the largest nodal and basal root $(\mathrm{cm})$ through a graduated scale; total volume of nodal, basal and total roots $\left(\mathrm{cm}^{3}\right)$ with graduated cylinder of $250 \mathrm{~mL}$ through mass displacement; and dry mass of nodal, basal and total roots $(\mathrm{mg})$ in greenhouse of forced circulation, regulated at $70{ }^{\circ} \mathrm{C}$ until constant weight.

The chemical and physical evaluation of the substrates was performed in the Laboratory of Soil, Leaf and Water Analysis (LAGRO) of the CEUNES/UFES (Table 1). The physical characteristics of the substrates were evaluated in the Laboratory of Physical Analysis of the CEUNES/UFES, where the determination of the dry density and porosity was performed (MAPA, 2007). The particle size (Table 1) was determined through dry sieving, sifting $100 \mathrm{~g}$ of each dry substrate in the air, coupled in a sieve compound with meshes $>4.75 ; 2.00$ to $4.75 ; 1.00$ to $2.00 ; 0.5$ to $1.00 ; 0.25$ to 0.5 and $<0.25 \mathrm{~mm}$, and agitated for 5 minutes. The retained fractions in each sieve were weighed and the percentages over the total weight of the samples were calculated.

For the statistical analysis, the date were subjected to variance analysis and the averages were compared by Tukey's test, at $5 \%$ significance, through the Genes software (Cruz, 2013).

Table 1. Chemical and physical characteristics of the substrates soil + organic compound, vermiculite, carbonized rice hull and commercial substrate utilized in the rooting of Piper nigrum cuttings cvs. Bragantina, laçará and Guajarina

\begin{tabular}{|c|c|c|c|c|}
\hline \multirow{2}{*}{$\begin{array}{l}\text { Characteristics } \\
\text { Chemicals }\end{array}$} & \multicolumn{4}{|c|}{ Substrates } \\
\hline & $s+C O$ & VERM & CRH & CS \\
\hline Total organic matter (dag kg-1) & 3.1 & 0.8 & 11.2 & 8.5 \\
\hline $\mathrm{pH}$ in $\mathrm{H}_{2} \mathrm{O}$ & 7.6 & 6.7 & 6.6 & 5.2 \\
\hline P Mellich (mg dm³) & 222.0 & 9.0 & 49.0 & 198.0 \\
\hline $\mathrm{Na}^{+}\left(\mathrm{mg} \mathrm{dm}^{-3}\right)$ & 910.0 & 97.0 & 170.0 & 510.0 \\
\hline $\mathrm{K}^{+}$changeable $\left(\mathrm{mg} \mathrm{dm}^{-3}\right.$ ) & 1920.0 & 160.0 & 570.0 & 990.0 \\
\hline $\mathrm{Mg}^{2+}$ changeable (cmol) & 1.7 & 0.5 & 0.3 & 3.2 \\
\hline $\mathrm{Ca}^{2+}$ changeable (cmol) & 5.0 & 0.5 & 0.6 & 7.8 \\
\hline $\mathrm{Ca}^{2+}+\mathrm{Mg}^{2+}$ changeable $\left(\mathrm{mmol}_{\mathrm{c}} \mathrm{dm}^{-3}\right)$ & 6.7 & 1.0 & 0.9 & 11.0 \\
\hline $\mathrm{Al}^{3+}(\mathrm{cmol})$ & 0.0 & 0.0 & 0.0 & 0.4 \\
\hline $\mathrm{H}^{+}+\mathrm{Al}^{3+}(\mathrm{cmol})$ & 1.0 & 0.9 & 0.8 & 4.7 \\
\hline $\mathrm{Zn}\left(\mathrm{mg} \mathrm{dm}^{-3}\right)$ & 14.1 & 1.0 & 3.0 & 15.2 \\
\hline $\mathrm{Fe}\left(\mathrm{mg} \mathrm{dm} \mathrm{m}^{-3}\right)$ & 83.0 & 299.0 & 23.0 & 206.0 \\
\hline $\mathrm{Mn}\left(\mathrm{mg} \mathrm{dm}^{-3}\right)$ & 85.0 & 18.0 & 29.0 & 45.0 \\
\hline $\mathrm{Cu}\left(\mathrm{mg} \mathrm{dm}{ }^{-3}\right)$ & 0.9 & 1.7 & 0.5 & 2.4 \\
\hline$B\left(\mathrm{mg} \mathrm{dm}^{-3}\right)$ & 1.15 & 0.30 & 0.55 & 1.22 \\
\hline CTC (†) (cmol) & 11.6 & 1.4 & 2.4 & 13.9 \\
\hline Base saturation (\%) & 92.1 & 61.0 & 74.7 & 74.2 \\
\hline Physicals & $s+C O$ & VERM & CRH & $C S$ \\
\hline Dry density $\left(\mathrm{kg} \mathrm{m}^{-3}\right)$ & 1202.45 & 186.15 & 123.27 & 303.59 \\
\hline Total porosity (\%) & 45.24 & 71.74 & 41.81 & 64.09 \\
\hline Particle sizes & \multicolumn{4}{|c|}{ Particle sizes distribution (\%) } \\
\hline$>4.75 \mathrm{~mm}$ & 0.00 & 1.32 & 1.77 & 0.07 \\
\hline 2.00 a $4.75 \mathrm{~mm}$ & 6.41 & 17.14 & 62.73 & 34.56 \\
\hline 1.00 a $2.00 \mathrm{~mm}$ & 14.43 & 26.10 & 25.83 & 43.36 \\
\hline 0.5 a $1.00 \mathrm{~mm}$ & 19.67 & 22.19 & 7.33 & 18.78 \\
\hline 0.25 a $0.5 \mathrm{~mm}$ & 22.49 & 16.05 & 1.67 & 2.31 \\
\hline$<0.25 \mathrm{~mm}$ & 37.01 & 17.21 & 0.67 & 0.92 \\
\hline
\end{tabular}

\section{Results and Discussion}

In the present work there was significant interaction between the factors cultivars and substrates for the variables nodal rooting, rooting, number of nodal roots and root volume (Table 1).
The higher survival percentage of cuttings was obtained in the vermiculite substrate with the cv. Guajarina (87.29\%), which did not differ from the cv. laçará (78.12\%) and, this, in its turn, did not statistically differ from the cv. Bragantina 
(60.95\%). The lowest survival percentage was found in the carbonized rice hull substrate, also in the cv. Guajarina (39.06\%), which did not differ from cv. Bragantina (50\%) and, this, in its turn, did not statistically differ from the cv. laçará (65.62\%). In the commercial substrate, the highest survival rates were with the cultivars laçará (68.72\%) and Guajarina (62.50\%), and the lowest with the cv. Bragantina (40.62\%) (Table 2). Magevski et al. (2011) obtained survival rates of $100 \%$ for
Piper arboreum, 98\% for Piper amplum and $89 \%$ for Piper sp. at 45 days, in cuttings cultivated in the Bioplant ${ }^{\circledR}$ substrate. According to Cunha et al. (2015) the substrates washed sand and commercial are indicated for higher rooting percentages of Piper hispidum with $81.56 \%$ and $81.33 \%$, respectively. However, for this species the substrates soil + bird manure and/or soil + guarana bark were the more indicated when the objective is achieving high quality seedlings.

Table 2. Rooting characteristics of the Piper nigrum cuttings cvs. Bragantina, laçará and Guajarina, in the substrates soil + organic compound, vermiculite, carbonized rice hull and commercial substrate

\begin{tabular}{|c|c|c|c|c|}
\hline \multirow[b]{2}{*}{ Evaluated characteristics } & \multirow[b]{2}{*}{ SUB } & \multicolumn{3}{|c|}{ Cultivars } \\
\hline & & Bragantina & laçará & Guajarina \\
\hline \multirow{3}{*}{ Survival (\%) } & VERM & $60.95 \mathrm{Ab}^{*}$ & $78.12 \mathrm{Aab}$ & $87.29 \mathrm{Aa}$ \\
\hline & $\mathrm{CRH}$ & $50.00 \mathrm{Aab}$ & $65.62 \mathrm{Aa}$ & $39.06 \mathrm{Cb}$ \\
\hline & CS & $40.62 \mathrm{Ab}$ & $68.72 \mathrm{Aa}$ & $62.50 \mathrm{Ba}$ \\
\hline \multirow{3}{*}{ Nodal rooting (\%) } & VERM & $57.87 \mathrm{Ab}$ & $78.25 \mathrm{Aab}$ & $87.50 \mathrm{Aa}$ \\
\hline & $\mathrm{CRH}$ & $50.00 \mathrm{Aab}$ & $62.50 \mathrm{Aa}$ & $39.25 \mathrm{Bb}$ \\
\hline & CS & $40.75 \mathrm{Ab}$ & $68.75 \mathrm{Aa}$ & $54.87 \mathrm{Bab}$ \\
\hline \multirow{3}{*}{ Rooting (\%) } & VERM & $60.93 \mathrm{Ab}$ & $78.25 \mathrm{Aab}$ & $87.50 \mathrm{Aa}$ \\
\hline & $\mathrm{CRH}$ & $50.00 \mathrm{Aab}$ & $67.25 \mathrm{Aa}$ & $39.25 \mathrm{Bb}$ \\
\hline & CS & $40.75 \mathrm{Ab}$ & $68.75 \mathrm{Aa}$ & $60.93 \mathrm{Bab}$ \\
\hline \multirow{3}{*}{ Number of nodal roots } & VERM & $4.47 \mathrm{Ab}$ & $12.59 \mathrm{Aa}$ & $6.68 \mathrm{Ab}$ \\
\hline & $\mathrm{CRH}$ & $4.31 \mathrm{Aa}$ & $5.62 \mathrm{Ba}$ & $3.29 \mathrm{Aa}$ \\
\hline & CS & $2.83 \mathrm{Ab}$ & $7.00 \mathrm{Ba}$ & $4.48 \mathrm{Aab}$ \\
\hline \multirow{3}{*}{ Volume of nodal $\operatorname{root}\left(\mathrm{cm}^{3}\right)$} & VERM & $0.3750 \mathrm{Ab}$ & $0.9520 \mathrm{Aa}$ & $0.5350 \mathrm{Ab}$ \\
\hline & $\mathrm{CRH}$ & $0.3125 \mathrm{Aa}$ & $0.3300 \mathrm{Ba}$ & $0.1725 \mathrm{Ba}$ \\
\hline & CS & $0.3000 \mathrm{Ab}$ & $0.6250 \mathrm{Ba}$ & $0.4850 \mathrm{ABab}$ \\
\hline
\end{tabular}

In the mixture soil + organic compound, comparing with the remaining studied substrates, it was verified that in spite of the best results of $P, K$, $\mathrm{Mg}, \mathrm{Ca}, \mathrm{Ca}+\mathrm{Mg}, \mathrm{Zn}, \mathrm{Mn}, \mathrm{B}$ and CTC, the highest density and lowest total porosity were observed with the highest distribution rate of particles in the smaller particle size $<0,25 \mathrm{~mm}(37.01 \%)$ and in the particle size from 0.25 to $0.5 \mathrm{~mm}$ (22.49\%) (Table 1).

The mixture soil + organic compound resulted in the soaking and a sealant layer on the surface of the substrate, which likely resulted in a higher mechanical impedance. The substrate also proportioned the developed of algae in its surface and the darkening of tissues in the proximal region of the cuttings, resulting unto necrosis, what very likely might be related to infection by some phytopathogenicmicroorganism, where the sum of these negative factors resulted in the subsequent death of $100 \%$ of the cuttings.

Black peppers seedling producers from the North of the Espírito Santo state utilize the soil in mixture with sand and organic matter, not purged, what turns possible the dissemination of important diseases in the orchards of that state, such as fusariosis and nematosis (Serrano et al., 2012). Substrate solarization would be a method of preventive control against the infection by phytopathogenic microorganisms and even sources of weed propagules, as observed by Thankaman et al. (2008), who verified the superiority of the solarized mixture soil + sand + corral manure $(2: 1: 1 \mathrm{v} / \mathrm{v})$, in the reduction of diseases and in the growth increase of $P$. nigrum roots, what indicates that, in mixtures involving soil and organic compounds, elimination techniques of phytopathogenic microorganisms are necessary. The usage of coconut fiber composted with vermicompost and Trichoderma in black pepper orchards minimizes the usage of chemical fungicides, in addition to the fact that the Trichoderma colonization of the root system of the seedlings helps in the prevention of field pathogen infections (Prasath et al., 2014). 
The rooting of black pepper cuttings occurs in the nodal (leaf axil) and basal region (Figure 1), placed above the incised region in the distal portion. Nevertheless, in this experiment some roots appeared in the median region, between the nodal and basal regions, as observed in the cr. Guajarina (Figure 1). This is due to hormonal stimulus through total immersion of the cuttings (Secundino et al., 2014) and the effect might have been potentialized by the cultivation of the cuttings in the vermiculite substrate. In this case, the usage of the auxin is necessary, since in its absence the rooting percentages for the Bragantina, laçará and Guajarina cultivars are low (Secundino et al., 2014).

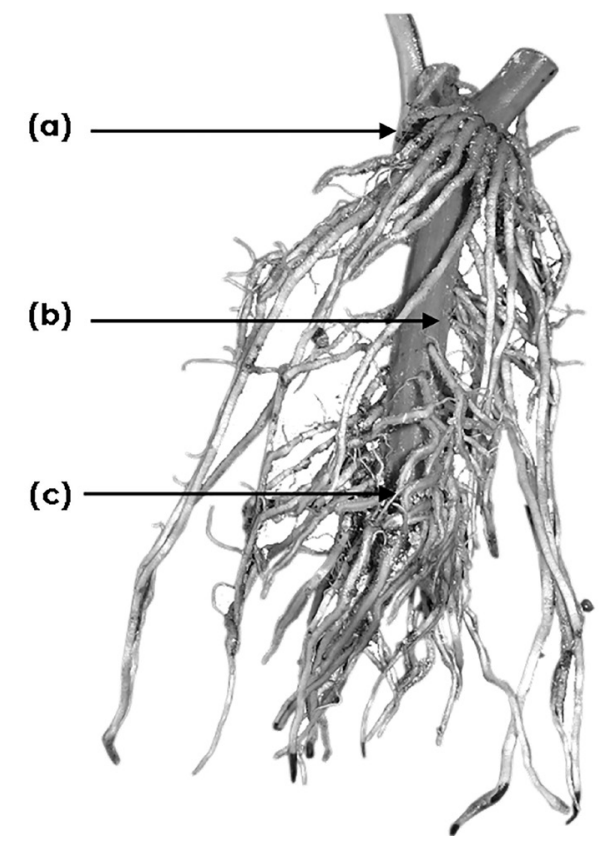

Figure 1. Rooted cutting of Piper nigrum cV. Guajarina in the vermiculite substrate, with roots formed in the nodal (a), median (b) and basal (c) regions.

The rooting easiness is a function of several factors, and according to Mouri et al. (2011) it is dependent of the genetics of the mother plants. The black pepper,cv. Bragantina, presents difficulties in this process, what turns imperative the usage of the auxin (Secundino et al., 2014).

The nodal rooting and the rooting in the basal or nodal regions in the vermiculite substrate reached the same average value, being higher in the cvs. Guajarina (87.50\%) and laçará (78.25\%), where the $\mathrm{cv}$. laçará did not statistically differ from the $\mathrm{cv}$. Bragantina as to the nodal $(57.87 \%)$ and basal (60.93\%) rooting (Table 2).

Nevertheless, in the present study, the basal rooting was higher (62.25\%) with the $\mathrm{cv}$. laçará, followed by the cv. Guajarina (52.83\%), independently of the substrate utilized (Table 3 ). The $\mathrm{cv}$. Bragantina presented inferior results of nodal rooting and rooting in the basal or nodal regions where the substrates did not statistically differ within each other, with averages of 49.54 and $50.56 \%$, respectively. Although no statistical difference was found for the rooting in the basal or nodal regions in the $\mathrm{cv}$. Bragantina within the studied substrates, the average values found for this characteristic in the vermiculite substrate (60.93\%) compared to the semi-carbonized rice hull (50\%) and to the commercial substrate $(40.75 \%)$ was superior in 10.93 and $20.18 \%$, respectively.

As to the quality of the root system in the vermiculite substrate, the characteristics number and volume of nodal root were higher in the cv. laçará.This cultivar, in the vermiculite substrate, produced an average of 12.59 roots, that is, approximately six roots more than the $\mathrm{cv}$. Guajarina and eight roots more than the cr. Bragantina (Table 2). Cuttings of Pipermikanianum Kunth Stend var. mikanianum presented higher 
number of roots in the vermiculite substrate, due to the good water retention and optimum space of air in the retention capacity, factors which turn possible the maintaining of an adequate supply of water for the rooting of the cuttings (Pescador et al., 2007).

The cv. laçará, independently of the substrate, also presented higher total root number, nodal and total root dry matter mass (Table 3). On the other hand, Serrano et al. (2012), by utilizing the mixture vermiculite + Pinus bark, verified that the cuttings of cv. Guajarina treated with $2000 \mathrm{mg} \mathrm{kg}^{-1}$ of IBA, produced higher dry mass of the root system if compared with the cvs. laçará and Cingapura.

Independently of the cultivar, the vermiculite was superior to the remaining substrates in increasing the characteristics basal rooting, basal and total root number and length of the bigger total and basal root (Table 4). Regarding the length of the largest nodal root, total and basal root volume, total, nodal and basal dry mass, the vermiculite did not statistically differ from the commercial substrate (Table 4). Oliveira et al. (2009) verified that the mixture perlite + vermiculite $(1: 1 \mathrm{v} / \mathrm{v})$ incremented the average length of roots in olive cuttings (Olea europaea L.). According to Mattana et al. (2009), the cuttings of the Piperaceae Pothomorphe umbellata (L.) Miq. in the mixture soil + bovine manure + commercial substrate + vermiculite $(3: 1: 1: 1 \mathrm{v} / \mathrm{v})$ presented higher values of dry and fresh root mass.

Table 4. Rooting characteristics of Piper nigrum cuttings in the substrates soil + organic compound, vermiculite, carbonized rice hull and commercial substrate

\begin{tabular}{|c|c|c|c|}
\hline \multirow[b]{2}{*}{ Evaluated characteristics } & \multicolumn{3}{|c|}{ Substrates' } \\
\hline & VERM & $\mathrm{CRH}$ & CS \\
\hline Basal rooting (\%) & $66.35 a^{*}$ & $42.33 \mathrm{~b}$ & $47.08 \mathrm{~b}$ \\
\hline Basal root number & $10.74 \mathrm{a}$ & $5.14 \mathrm{~b}$ & $5.53 \mathrm{~b}$ \\
\hline Total root number & $18.66 \mathrm{a}$ & $9.55 \mathrm{~b}$ & $10.30 \mathrm{~b}$ \\
\hline Length of the largest basal root $(\mathrm{cm})$ & $3.70 \mathrm{a}$ & $1.67 \mathrm{~b}$ & $2.55 \mathrm{~b}$ \\
\hline Length of the largest nodal root $(\mathrm{cm})$ & $3.60 a$ & $1.51 \mathrm{~b}$ & $2.79 \mathrm{a}$ \\
\hline Length of largest total root $(\mathrm{cm})$ & $3.97 \mathrm{a}$ & $1.71 \mathrm{c}$ & $2.99 \mathrm{~b}$ \\
\hline Basal root volume $\left(\mathrm{cm}^{3}\right)$ & $0.6583 a$ & $0.3300 \mathrm{~b}$ & $0.5550 \mathrm{a}$ \\
\hline Total root volume $\left(\mathrm{cm}^{3}\right)$ & $1.2775 \mathrm{a}$ & $0.6008 \mathrm{~b}$ & $1.0233 \mathrm{a}$ \\
\hline Basal root dry mass (mg) & $0.0316 a b$ & $0.0200 \mathrm{~b}$ & $0.0375 a$ \\
\hline Nodal root dry mass (mg) & $0.0358 a$ & $0.0175 \mathrm{~b}$ & $0.0383 a$ \\
\hline Total root dry mass (mg) & $0.0683 a$ & $0.0358 \mathrm{~b}$ & $0.0741 a$ \\
\hline
\end{tabular}
e CS (commercial substrate).

In the present work, the vermiculite and the commercial substrate were the ones which presented the highest total porosity (Table 1), what considerably contributed to the emission and growth of the root system. Dutra et al. (2012), also verified high porosity and low apparent density for the commercial substrate.

The vermiculite substrate presents low density (Table 1), which summed to its high porosity contributed to rate it as one of the best substrates, among those studied, concerning the root system characteristics. Higashikawa et al. (2010) also detected low density for the vermiculite substrate and, according to Abad et al. (2001), the perfect substrates density must be lower than $400 \mathrm{~kg} \mathrm{~m}^{-3}$, what was verified in the present work with the vermiculite (186. 15 $\mathrm{kg} \mathrm{m}^{-3}$ ) (Table 1). The same was verified with the commercial substrate $\left(303.59 \mathrm{~kg} \mathrm{~m}^{-3}\right.$ ) (Table 1), and another inferior to the recommended is the Plantmax ${ }^{\circledR}\left(278 \mathrm{~kg} \mathrm{~m}^{-3}\right)$, as quoted by Fermino \& Kämpf (2012). Dias et al. (2015) observed that the vermiculite proportioned to the mini-cuttings of Anadenanthera macrocarpa expressive root dry mass. These authors highlight that the weight of the root dry mass is directly correlated with the volume and quantity of roots, primordial factors for the better development of the seedlings after transplantation to the field.

The commercial substrate presents $\mathrm{pH}$ 5.2, situated in the recommended range for most crops according to Abreu et al. (2012) and also has an advantage of being one of the substrates with the best chemical composition regarding Mg, Ca, Ca + Mg, Zn, Cu, B, M.O. and CTC (Table 1). 
The commercial substrate also presents as an important characteristic a good composition of M.O., which might likely be a source humic substances directly related with root formation. Sharangi \& Kumar (2011) verified a better development of rooted cuttings of $\mathrm{cv}$. Panniyur-1 when they receive, in field, a supplementation of organic matter $(25 \%)$ with urea $(75 \%)$.

The organic matter is very important in the production of seedlings through rhizogenic stimulation, considering that it presents, in its constitution, humic substances (HS) such as the humic (HA) and fulvic (FA) acids. Zandonadi et al. (2010) verified that the activation of the $\mathrm{H}^{+}$ATPase of plasmatic membrane by HA essentially depends of mechanisms which utilize nitric oxide as messenger, specifically in the early development stages of the side roots.

In cuttins of Codianeum variegatum L. Rumph and hibiscus (Hibiscus rosa-sinensis L.) the concentrations of 579 and $970 \mathrm{mg} \mathrm{L}^{-1}$ of IBA and 14 and $50 \mathrm{mmol} \mathrm{L}^{-1}$ of $\mathrm{C}$ in the form of $\mathrm{HA}$ were those who promoted a higher accumulation of dry matter in the root system, respectively (Baldotto et al., 2012). Baldotto et al. (2013) also verified that the HA accelerates growth, anticipates and increases the flowering of gladiolus (Gladiolus L.).

The carbonized rice hull substrate was inferior compared to the remaining substrates in proportionating the characteristics length of largest total root, volume of basal and total root and total and nodal root dry mass. The carbonized rice hull also proportioned the worst results, similar to the commercial substrate, in the characteristics basal rooting, basal and total root number and length of the largest basal root. The carbonized rice hull also resulted in cuttings with inferior results of basal root dry mass, not differing of the vermiculite substrate (Table 4). The carbonized rice hull is a substrate which presented, as to its chemical characteristics the lowest CTC $(2.4 \mathrm{cmol})$ (Table 1) and was also the substrate which presented the lowest total porosity (41.81\%) (Table 1).

\section{Conclusions}

The vermiculite is the most indicated substrate, and the mixture soil + organic compound is not recommended for the rooting of cvs. Bragantina, laçará and Guajarina cuttings.

As cvs. Guajarina e laçará apresentam alta capacidade rizogênica no substrato vermiculite. E o substrato vermiculite é o mais adequado para a estaquia da cv. Bragantina.

\section{Acknowledgments}

To the Conselho Nacional de Desenvolvimento Científico e Tecnológico (CNPq).

\section{References}

Abad, M., Noguera, P., Burés, S. 2001. National inventory of organic wastes for use as growing media for ornamental potted plant production: case study in Spain. Bioresource Technology 77: 197-200.

Abreu, M.F., Dias, R.S., Abreu, C.A., Gonzalez, A.P. 2012. Reavaliação dos critérios constantes na legislação brasileira para análise de substratos. Bragantia 71(1): 106-111.

Baldotto, L.E.B., Baldotto, M.A., Soares, R.R., Martinez, H.E.P., Venegas, V.H.A. 2012. Adventitious rooting in cuttings of croton and hibiscus in response to indolbutyric acid and humic acid. Revista Ceres 59(4): 476-483.

Baldotto, M.A., Baldotto, L.E.B. 2013. Gladiolus development in response to bulb treatment with different concentrations of humic acids. Revista Ceres 60(1): 138-142.

Conab. Companhia Nacional de Abastecimento. Disponível em: http:// www.conab.gov.br/OlalaCMS/uploads/ arquivos/15_08_26_16_06_06_conjuntura_ de_pimenta-do-reino_2015_.pdf. Acesso em 22/05/2016.

Cruz, C.D. 2013. Genes: a software package for analysis in experimental statistics and quantitative genetics. Acta Scientiarum. Agronomy 35(3): 271-276.

Cunha, A.L.B., Chaves, F.C.M., Batista, A.C., Hidalgo, A.F. 2015. Propagação vegetativa de estacas de Piper hispidum Sw. em diferentes substratos. Revista Brasileira de Plantas Medicinais 17(4): 685-692.

Dias, P.C., Xavier, A., Oliveira, L.S., Correia, C.G., Barbosa, G.A. 2015. Tipo de miniestaca e de substrato na propagação vegetativa de angicovermelho (Anadenanthera macrocarpa (Benth.) Brenan). Ciência Florestal 25(4): 909-919.

Dutra, T.R., Grazziotti, P.H., Santana, R.C., Massad, M.D. 2012. Desenvolvimento inicial de mudas de copaíba sob diferentes níveis de sombreamento 
e substratos. Revista Ciência Agronômica 43(2): $321-329$

Fermino, M.H., Kämpf, A.N. 2012. Densidade de substratos dependendo dos métodos de análise e níveis de umidade. Horticultura Brasileira 30(1): 75-79.

Higashikawa, F.S., Silva, C.A., Bettiol, W. 2010. Chemical and physical properties of organic residues. Revista Brasileira de Ciências do Soil 34(5): 1743-1752.

Ibge. 2016. Instituto Brasileiro de Geografia e Estatística. Levantamento sistemático de produção agrícola: pesquisa mensal de previsão e acompanhamento das safras agrícolas no ano civil. Rio de Janeiro, 29(3): 1-79.

Magevski, G.C., Czepak, M.P., Schmildt, E.R., Alexandre, R.S., Fernandes, A.A. 2011. Propagação vegetativa de espécies silvestres do gênero Piper, com potencial para uso como porta enxertos em pimenta-do-reino (Piper nigrum). Revista Brasileira de Plantas Medicinais 13: 559-563.

Mattana, R.S., Franco, V.F., Yamaki, H.O., Maia e Almeida, C.I., Ming, L.C. 2009. Propagação vegetativa de plantas de pariparoba [Pothomorphe umbellata (L.) Miq.] em diferentes substratos e número de nós das estacas. Revista Brasileira de Plantas Medicinais 11 (3): 325-329.

MINISTÉRIO DA AGRICULTURA, PECUÁRIA E ABASTECIMENTO - MAPA. Instrução Normativa SDA No 17. (2007). Diário Oficial da União - Seção 1, no 99, 24 de maio de 2007. Métodos analíticos oficiais para análise de substratos para plantas e condicionadores de soil. Brasília.

Mouri, Y., Miyahara, F., Tsutsumi, Y., Kondo, R. 2011. Effect of combination treatment with ethephon and indole-3-butyric acid on adventitious rooting of Pinus thunbergii cuttings. Plant Growth Regulation 63(3): 271-278.

Oliveira, A.F., Chalfun, N.N.J., Alvarenga, A.A., Vieira Neto, J., Pio, R., Oliveira, D.L. 2009. Estaquia de oliveira em diferentes épocas, substratos e doses de AIB diluído em $\mathrm{NaOH}$ e álcool. Ciência e Agrotecnologia 33(1): 79-85.

Pescador, R., Voltoni, A.C., Girardi, C.G., Rosa, F.A.F. 2007. Estaquia de pariparoba-do-Rio Grande do Sul sob efeito do ácido indol-butírico em dois substratos. Scientia Agraria 8(4): 391-398.

Prado, G., Oliveira, M.S., Moreira, A.P.A., Lima, A.S., Souza, R.A., Alves, M.C. 2008. Determinação de aflatoxina $B_{1}$ em pimenta (Piper nigrum L.) e orégano (Origanum vulgare L.) por cromatografia em camada delgada e densitometria. Química Nova 31 (3): 514-517.
Prasath, D., Vinitha, K.B.,Srinivasan, V., Kandiannan, K., Anandaraj, M. 2014. Standardization of soil-less nursery mixture for black pepper (Piper nigrum L.) multiplication using plug-trays. Journal of Spices and Aromatic Crops 23(1): 1-9.

Secundino, W., Alexandre, R.S., Schmildt, E.R., Schmildt, O., Magevski, G.C., Martins, J.P.R. 2014. Rhizogenic behavior of black pepper cultivars to indole-3-butyric acid. Acta Scientiarum. Agronomy 36(3): 355-364.

Serrano, L.A.L., Marinato, F.A., Magiero, M., Sturm, G.M. 2012. Produção de mudas de pimenteirado-reino em commercial substrate fertilizado com adubo de liberação lenta. Revista Ceres 59(4): 512-517.

Sharangi, A.B., Kumar, R. 2011. Performance of rooted cuttings of black pepper (Piper nigrum L.) with organic substitution of nitrogen. International Journal of Agricultural Research 6(9): 673-681.

Simas, N.K., Lima, E.C., Kuster, R.M., Lage, C.L.S., Oliveira Filho, A.M. 2007. Potential use of Piper nigrum ethanol extract against pyrethroidresistant Aedes aegypti larvae. Revista da Sociedade Brasileira de Medicina Tropical 40(4): 405-407.

Thankaman, C.K., Dinesh, R., Eapen, S.J., Kumar, A., Kandiannan, K., Mathew, P.A. 2008. Effect of solarized potting mixture on growth of black pepper (Piper nigrum L.) rooted cuttings in the nursey. Journal of Spicies and Aromatic Crops 17(2): 103-108.

Trajano, V.N., Lima, E.O., Souza, E., Travassos, A.E.R. 2009. Propriedade antibacteriana de óleos essenciais de especiarias sobre bactérias contaminantes de alimentos. Ciência e Tecnologia de Alimentos 29(3): 542-545.

Zandonadi, D.B., Santos, M.P., Dobbss, L., Olivares, F.L., Canellas, L.P., Binzel, M.L., OkorokovaFacanha, A., Façanha, A.R. 2010. Nitric oxide mediates humic acids-induced root development and plasma membrane $\mathrm{H}^{+}$-ATPase activation. Planta (Heidelberg) 231: 1025-1036. 